\title{
COPROPHILOUS FUNGI FROM CONFINED DEERS IN PAVIA (LOMBARDIA, ITALY)
}

\author{
(Hongos coprófilos en ciervos confinados en Pavia (Lombardía, Italia)
}

\author{
Giuseppe Caretta* \& Edoardo Piontelli** \\ *Istituto di Micologia Medica, Universitá di Pavia Via S.Epifanio 14, \\ 27100 Pavia (Italia).** Universidad de Valparaiso, Escuela de Medicina, \\ Cátedra de Micología Casilla 92 V, Valparaíso (Chile).
}

Key words: Coprophilous fungi, deer, Zygomycetes, Ascomycetes, Hyphomycetes.

Palabras clave: Hongos coprófilos, ciervo, Zygomycetes, Ascomycetes, Hyphomycetes.

\section{SUMMARY}

Eighteen samples of fresh dungs were collected in spring time in order to establish the presence of coprophilous fungi in a group of deersconfined in a private park located near Pavia (Lombardia, Italy). A total of 40 genera and 57 species distributed in: 65 Zygomycetes, 56 Ascomycetes, 100 Hyphomycetes and 2 Basidiomycetes $(n=223)$ was detected.

Dominant species were: Mucor hiemalis, Graphium penicillioides, Fusarium verticillioides, Mucor racemosus, Saccobolus versicolor, Chaetomium bostrychodes and Doratomyces columnaris.

It is also noted the diversity and density of some species in this kind of dungs and new records of some Ascomycetes in this geographic area, such as: Ascodesmis sphaerospora, Coprotus disculus, Sphaerodes fimicola, Zopfiella leucotricha, Kernianitida and Thelebolus crustaceus are also mentioned.

\section{INTRODUCTION}

Coprophilous fungi play several roles in soil and grassland ecosystem, specially in the decomposition and mineralization of herbivore feces (Angel \& Wicklow, 1975). The quantification, distribution and the structure of coprophilous community are related to different physiological, ecological and biogeographical features which are closely linked to the kind and composition of the substratum as well as to the surrounding terrestrial habitat (Sinh \& Webster, 1973; Safar \& Cooke, 1988 a,b; Kuthubutheen \& Webster, 1986)

The complexity of fecal substrata is similar to soil sytems and exhibits a high degree of spatial and temporary

\section{RESUMEN}

Con el fin de determinar la presencia de hongos coprófilos en un grupo de ciervos confinados en un parque privado en las cercanias de Pavia (Lombardia, Italia), se colectaron 18 muestras de excrementos frescos en un periodo primaveral.

Se detectaron un total de 40 géneros y 57 especies distribuidas en: 65 Zygomycetes, 56 Ascomycetes, 100 Hyphomycetes y 2 Basidiomycetes $(n=223)$.

Las especies dominantes fueron Mucor hiemalis, Graphium penicillioides, Fusarium verticillioides, $\mathbf{M u}$ cor racemosus, Saccobolus versicolor, Chaetomium bostrychodes y Doratomyces columnaris.

Se comenta la diversidad y densidad de algunas especies en este tipo de excrementos y se mencionan nuevos recod de algunos Ascomycetes en ésta área geográfica, tales como:Ascodesmis sphaerospora, Coprotus disculus, Sphaerodes fimicola, Zopfiella leucotricha, Kernia nitida y Thelebolus crustaceus.

heterogeneity inbiotic and abiotic components, thus making difficult to measure in situ (Miller, 1995). Moreover, changes in species composition during succession affect measurement of fungal diversity (Wicklow \& Moore, 1974, Kuthubutheen \& Webster, 1986).

Italian contributions to the occurrenceand distribution of coprophilous fungi in animal dung remain scarse and limited to certaingroup of animals. Data covering this country are still rare and referred to the mycota of rabbit dung from Piemonte (Vesco dalet al., 1967) and the fungal population colonizing the horse, goat and sheep dung in Lombardia (Caretta et al., 1994). 
The present survey was therefore undertaken to acquire further taxonomic informations about the occurrence and diversity of coprophilous fungi from Roe deer dung confined to a same kind of food in a $3.000 \mathrm{~m}^{2}$ park located in the suburbs of Pavia (Lombardia). An ecological event which we considered interesting because of the unfrecuent association of this animals with a purely antropophilic habitat.

\section{MATERIALS AND METHODS}

The dungs of 18 deers were collected in 1995 in the private park of S. Martino Siccomario a suburb of Pavia. Samples were collected in spring. These animals had been fed with hay, grass and cereals, in particular maize, all year long.

Eighteen samples of fresh dung were singly collected in sterile containers in different park areas. Each sample was divided into three sub samples of approximately equal size, and placed on moist blotting-paper in individual sterile Petri dishes.

Samples were incubated for 60 days at room temperature $\left(19-22{ }^{\circ} \mathrm{C}\right)$ and daily exposed to natural light. Substratum moisture was maintained by periodic additions of sterile destilled water for up to 30 days.

Dung was inspected for fungal fructîfications at regular intervals during this incubation period.

Isolations were usually attempted in 2 media, PDA and agar with decoction of the same deer feces. Moreover in most cases macroscopic and microscopic observations were carried out directly in living material of the dung.

No attempt was made to count the total number of colonies of each species in a single Petri dish. Species occurring more than once over the three replicate dishes were counted as one occurrence. Portions of dung samples and slides of some fungal species are retained at the Institute of Medical Mycology of Pavia. The microscopic preparation of fungi were mounted in cotton-blue and lactophenol or simply lactophenol.

\section{RESULTS AND DISCUSSION}

A total of 223 isolates representative of : 65 Zygomycetes, 56 Ascomycetes, 100 Hyphomycetes and two Basidiomycetes was obtained from 18 deer fecal samples. Fiftysix species belonging to 41 genera were recorded (Table. 1). The dominant species occurring over $50 \%$ in 18 samples, were Chaetomium bostrychodes, Doratomyces columnaris, Fusarium verticillioides, Graphium penicillioides, Mucor hiemalis, M. racemosus and Saccobolus versicolor (Table. 1, Figure A).
Frequent species occurring between $30-49 \%$ were Botryotrichum piluliferum, Piptocephalis lepidula, Scopulariopsis brevicaulis, S. brumptii, Sordaria fimicola and Penicillium spp. (Table. 1).

The rare species isolates only once ( $8 \%)$, represented several groups of fungi mostly cosmopolitan coprophilous Ascomycetes (10/18), which are common in different kinds of feces collected from herbiverous animals such as : Ascobolus perplexans, Ascodesmis sphaerospora, Chaetomium globosum,Ch.murorum,Ch.piluliferum, Coprotus disculus, Podospora miniglutinans, Sphaerodes fimicola, Sporormiella minima, and Zopfiella leucotricha. (Table. 1). Their scarce propagules density in Petri dishes, may not reflect their occurrence in the habitat and this may be due to the kind of food eaten by these animals (pellets), a slower time of fructification, a clear interspecific competition between the fecal microbiota (bacteria and fungi), or to the conditions of incubations (Wicklow \& Moore, 1974; Safar \& Cooke, 1988 b).

The total number of species developing on these feces was higher than in other study in the same geographical locality with different types of dung (Caretta et al, 1994)

Most of the fungal groups exhibited fructifications usually about the 5 (Zygomycetes) to 10-25 days (AscoDeuteromycetes and Basidiomycetes). Later on (30-60 days), only a few of them (Asco and Deuteromycetes) appeared when the moisture of the substratum fell due to the fact that the Petri dishes were not added sterile water. Main taxa were some: Penicillium spp., Coprotus disculus, Kernia nitida, Thelebolus crustaceus, Doratomyces stemonitis and Scopulariopsis brevicaulis. However many of them made their appearance from 10 to 20 days. This coincides with the influence of the activity of water in the succession of coprophilous fungi described by Kuthubutheen \&Webster (1986).

The mucoraceous and Hyphomycetes species are common of herbivore excrements of most animals, and may also occur on other types of decaying organic matter.

The presence of some of these fungi in deer dung, can be probably attributed to their ability to colonize the maize stored, one of the ingredients in the food for deers.

M.hiemalis the most dominant fungi isolated, is common in different herbivorous feces (Harper \& Webster, 1964, Dal Vesco et al, 1967), usually appear after 3-5 days incubation with their parasites, specially Chaetocladium brefeldii and in our case with Piptocephalis lepidula. It is also one of the most common and representative soil fungi and itscompetitive ability, especially in agricultural soil, is due to the fact that they germinate and grow rapidly when stimulated by soluble nutrients, being even able to exclude Trichoderma harzianum from specific habitat (Wardle et al.,1993). Yet as Shearer (1995), states it this situations is surprisingbecause the Mucorales are considered $r$-selected and poor competitors. The scarse presence of $T$. harzia- 
Table 1. Relative frecuency of total coprophilous fungi on fecal deer substrata

\begin{tabular}{|c|c|c|c|c|c|c|c|c|c|c|c|c|c|c|c|c|c|c|c|c|}
\hline Number of samples & $\mathbb{1}$ & 2 & 3 & 4 & 5 & 6 & 7 & 8 & 9 & 10 & 11 & 12 & 13 & 14 & 15 & 16 & 17 & 18 & n & $\%$ \\
\hline Acremonium sp. & & & & & & + & & & & & & & & & & & + & & 2 & $\mathbf{0 , 8 9}$ \\
\hline Acremonium strictum W.Gams & & & & & & & & & & & & & & + & & & & & 1 & 0,44 \\
\hline Alternaria sp. & & & & & & & & & & & & & & & + & & & & 1 & 0,44 \\
\hline Ascobolus furfuraceus Pers \& Hook & & & & & & & & & & & & & & & + & + & & & 2 & 0,89 \\
\hline A. perplexans Massee \& Sal. & & & & & & & & & & & + & & & & & & & & 1 & 0,44 \\
\hline Ascodesmis sphaerospora Obrist & & & & & & & & & & & & & & + & & & & & 1 & 0,44 \\
\hline Aspergillus clavatus Desmaz. & & & & & & & & & & & & & + & & & . & + & + & 3 & 1,34 \\
\hline Botryotrichum piluliferum Sacc. \& March & & & & & + & & & & & & & & + & + & + & + & & + & 6 & 2,69 \\
\hline Chaetocladium brefeldii v.Tiegh \& Le Mond & & & & & & & & & & & & & & + & + & & + & + & 4 & $\overline{1,79}$ \\
\hline Chaetomium bostrychodes Zopf & + & & & + & & & + & & & + & & + & + & + & + & + & + & + & 11 & 4,93 \\
\hline C.globosum Kunze & & & & & + & & & & & & & & & & & & & & 1 & $\overline{0,44}$ \\
\hline C.murorum Corda & & & & & & & & & & & & & & & & & & + & 1 & 0,44 \\
\hline C.piluliferum Daniels & & & & & & & & & & & & & & & & + & & & 1 & 0,44 \\
\hline Cladorrhinum foecundissimum Sacc.\&March & & & + & & & & & & & & & + & & & & & & & 2 & 0,89 \\
\hline Coprinus sp. & & & & & + & & & & & & & & & & + & & & & 2 & 0,89 \\
\hline Coprotus disculus Kimbr.,Luck-Allen \& Cain & & & & & & & & & & + & & & & & & & & & 1 & 0,44 \\
\hline Doratomyces columnaris Swart & + & & + & & + & + & + & + & & + & + & + & + & & & & + & & 11 & $\underline{4,93}$ \\
\hline D.stemonitis (Pers:Fr.) Morton \& Smith & & & & & & + & & & & & & & & & & & + & + & 3 & $\overline{1,34}$ \\
\hline Fusarium verticillioides (Sacc.) Nirenb. & + & + & + & + & + & + & + & + & + & + & + & + & + & & & & + & & 14 & 6,27 \\
\hline F.solani (Mart.) Sacc. & & & & & + & & & & & & & & & & & & & + & 2 & $\overline{0,89}$ \\
\hline Fusarium sp. & & & & & & & & & & & & & & + & & & & + & 2 & 0,89 \\
\hline Gilmaniella humicola Barron & & & & & & & & & & & & & & & & & & + & 1 & 0,44 \\
\hline Gliocladium roseum Bainier & & & & & & & & & & & & & & & & & + & + & 2 & 0,89 \\
\hline Graphium penicillioides Corda & + & + & + & + & + & + & + & + & + & + & + & + & + & & + & & + & & 15 & 6,72 \\
\hline G.putredinis (Corda) Hughes & & & & & & & & & & & & & & $\cdot$ & & & + & & 1 & $\overline{0,44}$ \\
\hline Iodophanus carneus (Pers.) Korf & & & & & & & & + & & & & + & & & & & & & 2 & 0,89 \\
\hline Kernia nitida (Sacc.) Nieuwl. & + & & & & & & & & & + & & & & & & & & & 2 & 0,89 \\
\hline Mortierella reticulata V.Tiegh.\& Le Mond & & & & & & & & & & & & + & & & & & & & 1 & 0,44 \\
\hline Mucor bainieri Mehrotra \& Baijal & & & & & + & & & & & & & & + & + & + & & & + & 5 & 2,24 \\
\hline M.hiemalis Wehmer & + & + & + & + & + & + & + & + & + & + & + & & + & + & + & + & + & + & 17 & $\underline{7,62}$ \\
\hline M.plumbeus Bonord & & & + & & & + & & & & & & & & + & & + & & & 4 & $\overline{1,79}$ \\
\hline
\end{tabular}


Table 1.(Continuation)

\begin{tabular}{|c|c|c|c|c|c|c|c|c|c|c|c|c|c|c|c|c|c|c|c|c|}
\hline Number of samples & $\mathbb{1}$ & 2 & 3 & 4 & 5 & 6 & 7 & 8 & 9 & 10 & 11 & 12 & 13 & 14 & 15 & 16 & 17 & 18 & $\mathbf{n}$ & $\%$ \\
\hline M.racemosus Fresen. & + & + & + & & + & + & + & + & + & & + & + & + & & + & & + & + & 14 & 6,27 \\
\hline Penicillium spp. & + & & & & + & & & + & + & & & & + & + & & & + & & 7 & 3,13 \\
\hline Phycomyces blakesleanus Burgeff & & & & & & & & & & & & & & + & & & & & 1 & $\overline{0,44}$ \\
\hline Pilobolus kleinii V.Tieghem & & & & & & & & & & & & & & + & & & & + & 2 & 0,89 \\
\hline Podospora miniglutinans Mirza \&Cain & & & & & & & & & & & & & & & & & & + & 1 & $\overline{0,44}$ \\
\hline P.setosa (Wint.) Niessl. & + & & & & & & & & & & & & & & + & & & + & 3 & 1,34 \\
\hline Rhizopus stolonifer (Ehremb.:Fr.) Vuill. & & & & & & & & & & & & & & + & & & & & 1 & 0,44 \\
\hline Saccobolus citrinus Boudier \&Torrend & & & + & & + & & + & & & + & & & & & & & & & 4 & 1,79 \\
\hline S.versicolor (P.Karst.) P.Karst. & & & + & + & + & + & + & + & + & & & + & + & + & + & + & + & + & 14 & $\underline{6.27}$ \\
\hline Scopulariopsis brevicaulis (Sacc.) Bain. & + & + & & & + & & + & & & + & + & & + & & & & + & & 8 & $\overline{3,58}$ \\
\hline Sporormiella minima(Auersw) Ahmed \& Cain & & & & & & & & & & & & & & + & & & & & 1 & 0,44 \\
\hline Stilbella erytrocephala (Ditmar) Lindau & & & & & & & & & & & & & & + & & + & + & & 3 & 1,34 \\
\hline Syncephalis cornu V.Tiegh.\& Le Monn. & & & & & & & & & + & & + & & & & & & & & 2 & 0,89 \\
\hline S.reflexa v.Tiegh. & & & + & & & & & & & & & & & & & & & + & 2 & 0,89 \\
\hline Thamnidium elegans Link & & & & & + & & & & & & & & & + & + & & + & + & 5 & 2,24 \\
\hline Thelebolus crustaceus (Fuckel) Kimbr. & & & & & & & & & & & + & & & & & & + & & 2 & 0,89 \\
\hline Trichoderma harzianum Rifai & & & & & + & & & & + & & & & & & & & & & 2 & 0,89 \\
\hline Trichurus spiralis Hasselbr. & & & & & & & & & & & & & & & & & + & + & 2 & 0,89 \\
\hline Volutella ciliata Alb. \& Schw. ex Fr. & & & & & & & & & & & & & & & & & + & & 1 & 0,44 \\
\hline Zopfiella leucotricha (Speg.) Malloch \& Cain & & & & & & & & & & & + & & & & & & & & 1 & 0,44 \\
\hline
\end{tabular}


num, a species which is assumed to be not coprophilous can be explained by its appearance in the surrounding soil.

Dung is thusa mechanism for the dispersion of some soil fungi, like $\boldsymbol{F}$. verticillioides ( $F$. moniliforme), one of the most prevalent field fungi occurring in a great variety of plant hosts. Their frequency in dung can be explained because it is one of the organisms associated with corn-based feeds and by the ability to adapt easily to this new ecological niche.

Fusarium verticillioides, anamorph of Gibberella moniliformis, was found on horse dung (Piontelli et al., 1981) and on cow dung (Dominik \& Majchrowicz, 1970). It has been suspected of being involved in human and animal diseases and has been shown to be toxic for a variety of experimental animals. (Kriek etal., 1981 a,b). The new group of mycotoxins, called fumonisins, was characterized in 1988 by Bezuidenhout et al.

Doratomyces columnaris, has been isolated by Swart (1967) on dung pellets of hares collected in the Melville Koppies Nature Reserve in Johannesburg. The main characteristic features on which the specific epithet isbased, uponare thevery short synnema tapped by a small almost flat head, from which the conidia arise in a column.

D. columnaris in our study was the species occurring with significantly higher frecuency. In a previous study, this species was found on horse dung collected in the province of Pavia, Lombardia (Caretta et al., 1994).

Among the synnematous fungi, Graphium penicillioides is another significant fungal species restricted to deer dung. Graphium species are commonly found on woody substrata or plant debris and animal dung. They are frequently found as anamorphs of Ascomycetes, Ophiostoma, Petriella, Petriellidium. G. penicillioides was reported by Ellis (1971), on wood of Populus; the host of this species is Zea.

Scopulariopsis species, anamorphs of Microascus, are commonly found on all types of decaying organic materials; they are quite frequently isolated from soils.

The species most frequently found on animal dung (ping, monkey, camel, horse, goat, cow and sheep) was $S$. brevicaulis (Udagawa \& Takada, 1971; Dominik \& Majchrowicz 1970, Piontelli et el., 1981; Caretta et al., 1994). It is a cellulolytic and proteolytic fungus associated sometime in humans onychomycosis, ulcerating granuloma and chronic granulomatous inflammation of tendon sheaths and muscle (Emmons et al., 1977). S. brevicaulis has the ability to attack arsenic compounds with the production of volatile gas identified as trime-thylarsine (Challenger, 1954).

Among the Ascomycetes on deer dung only some species were predominant: C. bostrychodes, Saccobolus versicolor and $S$. citrinus.

Chaetomium bostrychodes was present in abundance in a relatively high number of deer dung. This species has a cosmopolitan distribution with the principal substrata being dung, seeds, soil or animal hairs .

This fungus is able to decompose cellulose (Vesco dal et al., 1967) and is of interest because of mycotoxin production.

Larvae of the sciarid fly Licorella mali avoided ascomata of Ch. bostrychodes that had growth on rabbit dung, but consumed the fruit bodies of other coexisting coprophilous fungi (Helsel \& Wicklow, 1978). The presence of larvae of $\boldsymbol{L}$. mali in rabbit dung decreased the number of sporulating species of coprophilousfungi, and increased the relative abundance of Ch. bostrychodes (Wicklow \& Yocom, 1982). For Wicklow $(1979,1988)$, Ch. bostrychoides has effective mechanical and chemical defenses against fungus feeding arthropods; this fact is related to the toxicity of Chaetomium metabolites as chaetomin, chaetocins, chaetoglobosins and other metabolites (Udagawa et al., 1979, Udagawa, 1984).

Saccobolus versicolor is the most variable species of the genus Saccobolus (Brummelen, 1967). Apart from the variation in the shape and structure of the fruit-bodies, there is a considerable variation in pigmentation of these, ones the size of the ascospores and the variation of the episporium. For Brummelen (1967), it is impossible to distinguish more or less constant forms within the species.

With regard to other fungal taxa found on the deer dung, some are known only or prevalently from dung as Oedocephalum glomerulosum, Stilbella erytrocephala or Syncephalis cornu (Jeffries \& Kirk, 1976), others are interesting species as Mortierellareticulata and Phycomyces blakesleanus. These rarely collected fungi tell us little about their habitat, but sometimes from these few findings, valuable ecological data can be extracted.

Another interesting species recorded on deer dung and native of Europe, was Z. leucotricha (=Tipterospora leucotricha (Speg) Lundq.). Originally this fungus was collected by Spegazzini (1878) on rotten branches of Sambucus nigra from Conegliano, Venezia, Italy and named Sordaria leucotricha. All the synonyms species examined by Lundqvist (1969), were found on various herbaceous material and seeds. On dung this species was not known. A synopsis of the genus Zopfiella and generic delimitation of Zopfiella, Podospora and Tripterospora was proposed by Guarro et al., 1991.

Many of coprophilous fungi found in the present study, were listed by various authors on deer dung and the feces of other animals (Lundqvist, 1972; Richardson, 1972; Parker, 1979; Bell, 1983).

Bell \& Mahoney (1995), have observed that the dung from domesticated animals that receive regular intestinal drenches to rid them of internal parasites, shows a disappointing lack of fungi growing on it.

Most fungi occurring on deer dung are anamorphs 
of Ascomycota, particulary of genera belonging to the formerly so called"Discomycetes " and to the "Pyrenomycetes", some of which are coprophilous and typical components of the fungal succession on dung (Seifert et al., 1983).

Despite the complexity of the fungal population within alimentary canal on deer, the gross composition of the mycota of a particular animals is remarkably stable in their ecotope and tends to be characteristic for these animals. The main differences in fungal composition from animal to animal is difficult to be related to a specific cause, but it is mainly influenced to the kind of food, like grasses, forages and grains, the size of animal, the geographic localization, and interspecific competitive interactions by compounds which inhibit or stimulate the growth of some fungi and other biotic and abiotic factors.

\section{Figure A. Frequency (\%) of dominant species isolated in deer dung}

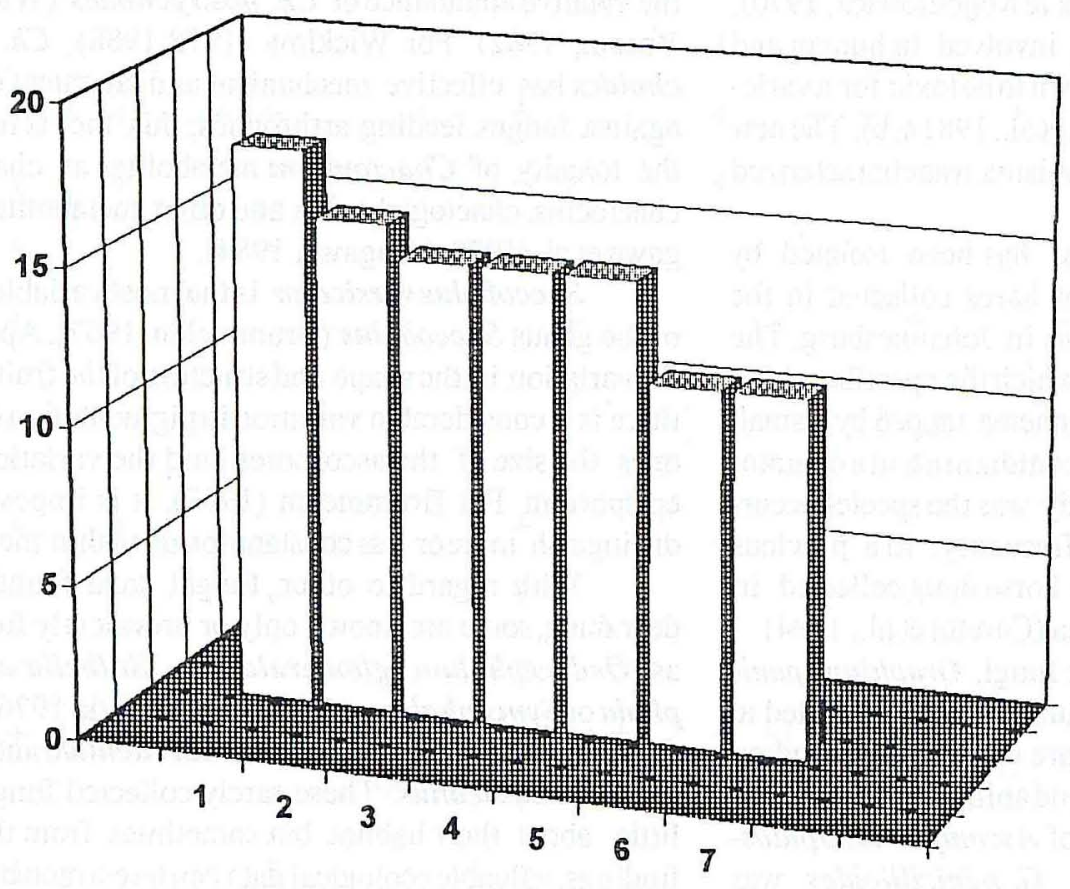

1.- Mucor hiemalis

2.- Graphium penicillioides 3.- Fusarium verticillioides 4.- Mucor racemosus 5.- Saccobolus versicolor 6.- Chaetomium bostrychodes 7.- Doratomyces columnaris

\section{REFERENCES}

Angel, K. \& Wicklow,D.T. (1975). Relationships between coprophilous fungi and fgecal substrates in a Colorado grassland. Mycologia 67:63-74

Bell, A. (1983). Dung fungi. An illustrated guide to coprophilous fungi in New Zealand. Victoria University Press. Wellington, N.Z.

\& Mahoney, D. P. (1995) Coprophilous fungi in New Zealand I, Podospora species with swollen agglutinated perithecial hairs. Mycologia 87:375-396

Bezuidenhout, S. C.; Gerdelblom, W.C.A.; Gorst-Allman, C.P.; Horak,R.M.; Marasas, W.F.O.; Spiteller,G. \& Vleggaar, R. (1988). Structure elucidation of fumonisins, mycotoxins from Fusarium moniliforme. J.Chem.Soc.Chem. Commun. 743-745

Brummelen, J. van. (1967). A word monograph of the genera Ascobolus and Saccobolus. Persoonia, Suppl. 1: 1-260

Caretta, G.; Mangiarotti, A.M. \& Piontelli, E. (1994). Coprophilous fungi on horse,goat and sheep dung from Lombardia (Italy). Mycologia Italiana 2:11-20

Challenger, F.; Lisle, D.B. \& Dransfield, P.B. (1954). Biological me thylation. 14. The formation of trimethylarsine and dimethyl selenide in mould cultures from methyl sources containing $14 \mathrm{C}$. J. Chem. Soc. 1760-1771

Dominik, T. \& Majchrowicz, I. (1970). Further contribution to the knowledge of keratinolytic and keratinophilic fungi of the region of Szczecin--Keratinolytic and keratinophilic fungi in the excrements of farm animals. Ekol.Pol. 18:1-41

Ellis, M.B. (1971). Dematiaceous Hyphomycetes Commonw. Mycol. Inst. Kew.

Emmons, C. W.; Binford,C.H.; Utz, J.P. \& Kwong-Chung, K.J. (1977). Medical mycology. Lea \& Febiger, Philadelphia.

Guarro, J.: Cannon,P.F. \& Van der AA,H.A .(1991) A synopsis of the 

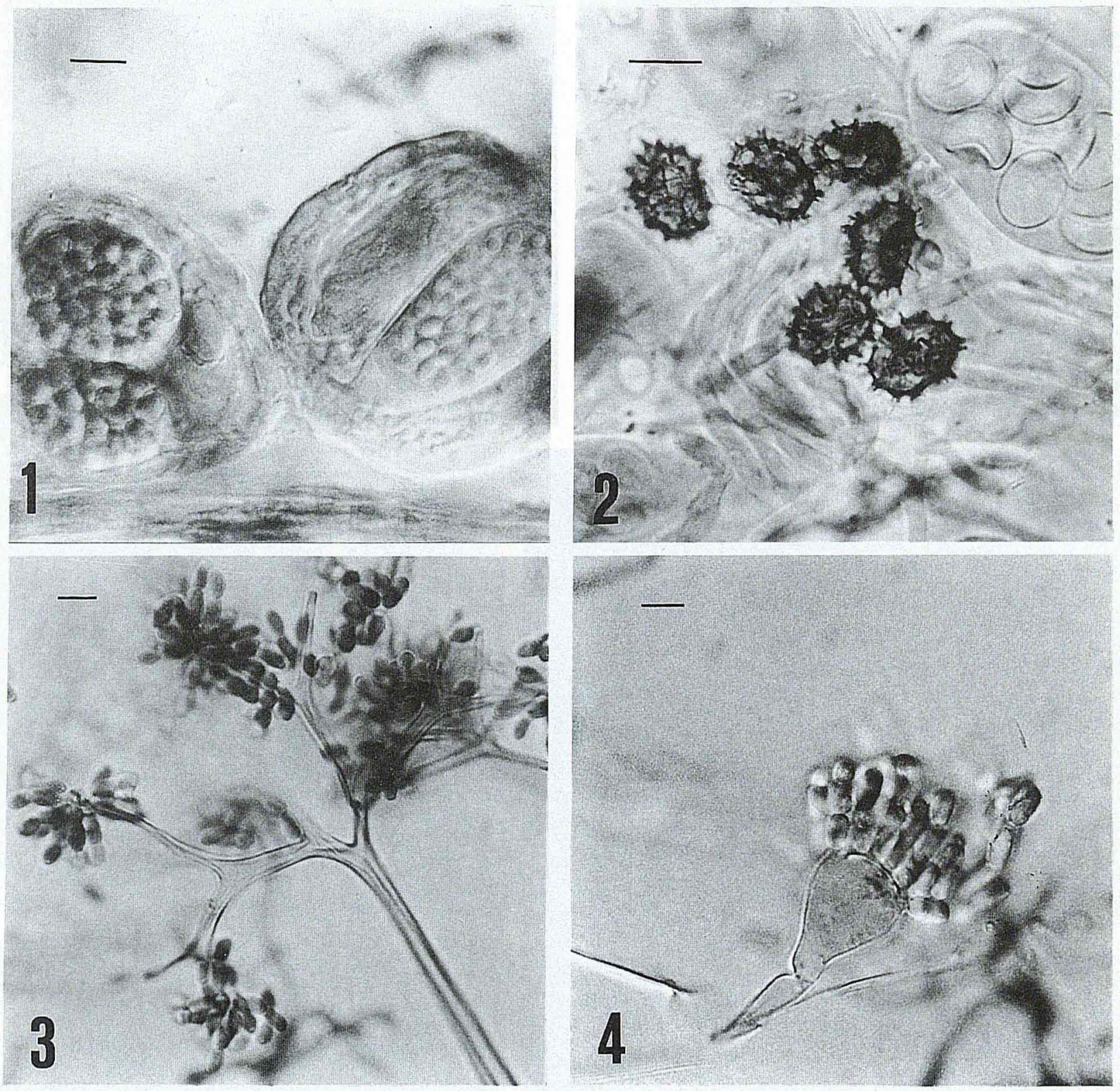

Figures. 1. Thelebolus crustaceus, ascus and ascospores $(\mathrm{Bar}=50 \mu \mathrm{m})$. 2. Ascodesmis sphaerospora, ascus and mature ascospores $(\mathrm{Bar}=20 \mu \mathrm{m})$. 3. Piptocephalis lepidula, dichotomously branched sporangiosphore and conidia $(\mathrm{Bar}=8 \mu \mathrm{m})$. 4 . Syncephalis cornu, terminal swelling merosporangia and conidia $(\mathrm{Bar}=10 \mu \mathrm{m})$. 5.Syncephalis reflexa, merosporangia and conidia $(\mathrm{Bar}=10 \mu \mathrm{m})$. 6. Cladorrhinum foecundissimum, conidiogenous cell and conidia $(\mathrm{Bar}=10 \mu \mathrm{m}) .7-8$. Mortierella reticulata, sporangiophores and conidia $(\mathrm{Bar}=20 \mu \mathrm{m})$. 9. Sepedonium hialinospinosum, conidia $(\mathrm{Bar}=10 \mu \mathrm{m}) .10$. Kernia nitida, ascomata and circinate hair $(\mathrm{Bar}=50 \mu)$. 11. Saccobolus citrinus, ascospore clusters $(\mathrm{Bar}=10 \mu \mathrm{m}) .12$. Saccobolus depauperatus, ascospore clusters $(\mathrm{Bar}=10 \mu \mathrm{m})$. 13. Ascobolus perplexans, ascospores with a loose episporium $(\mathrm{Bar}=10 \mu \mathrm{m})$. 14. Zopfiella leucotricha, bicellular ascospores and hialine hairs of the upper part of the ascomata $(\mathrm{Bar}=5 \mu \mathrm{m})$. 15. Coprotus disculus, ascus and young ascospores $(\mathrm{Bar}=10 \mu \mathrm{m})$. 16. Sphaerodes fimicola, reticulate ascospores $(\mathrm{Bar}=10 \mu \mathrm{m})$. 

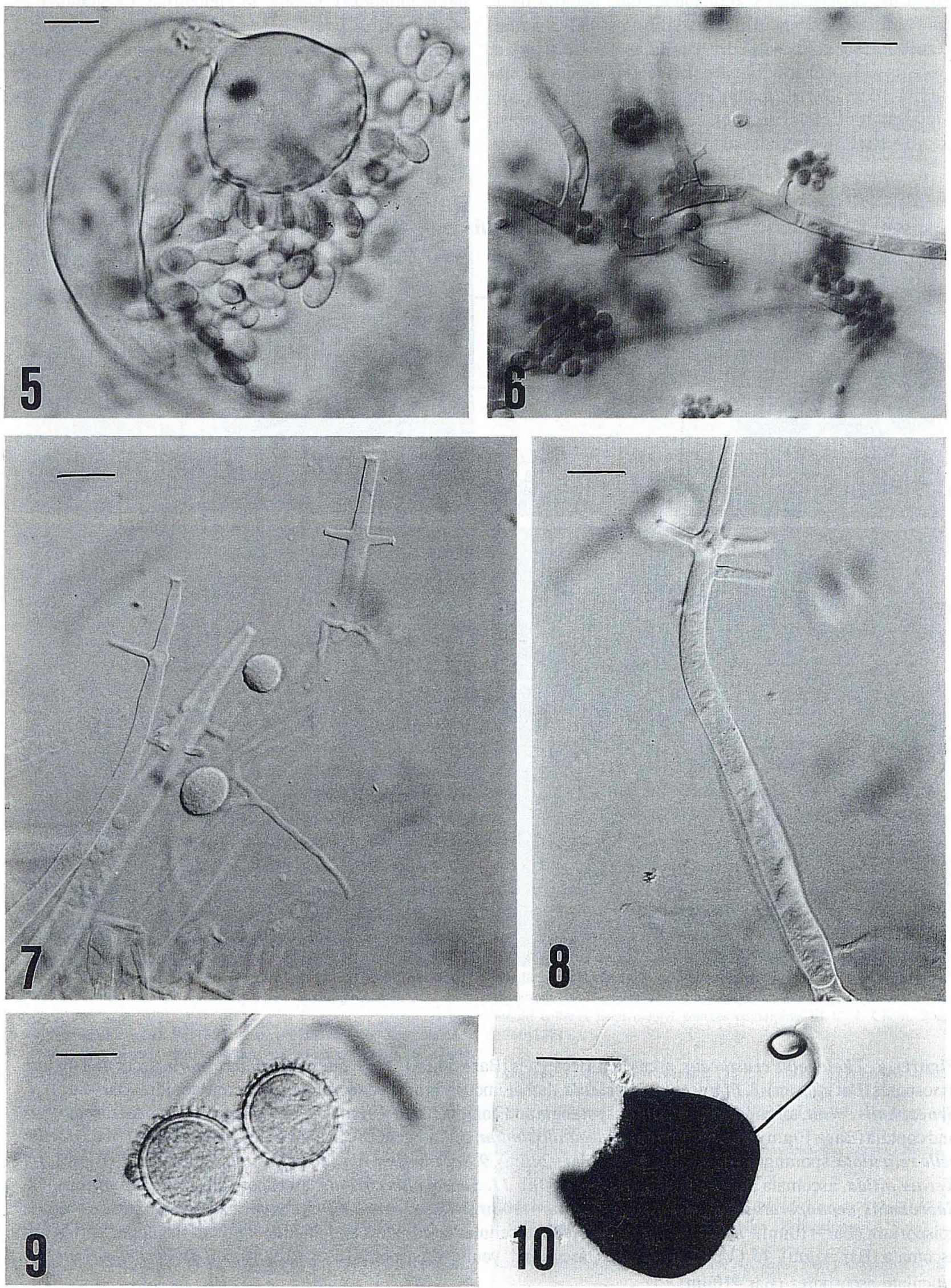

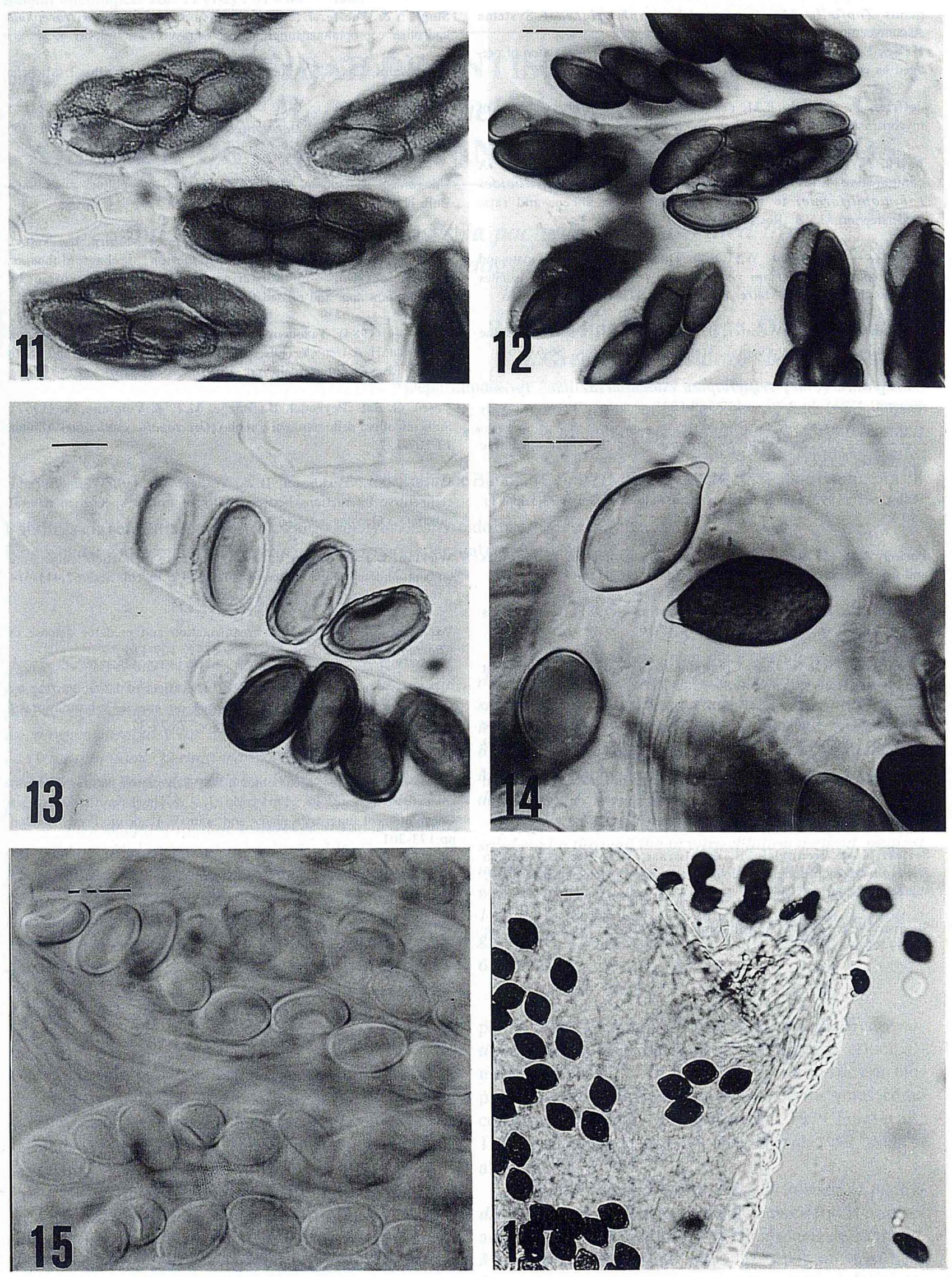
genus Zopfiella (Ascomycetes, Lasiosphaeriaceae) Systema Ascomycetum 10:79-112

Helsel, E. D. \& Wicklow, D.T. (1978). Arthropod colonization of preaged as compared with fresh feces. Can.Entomol. 110:217-222

Jeffries, P. \& Kirk, P.M. (1976). New technique for isolation of mycoparasitic Mucorales. Trans. Br. mycol. Soc. 66:541-543

Kriek, N. P.J.; Kellerman, T.F. \& Marasas, W.F.O. (1981). A comparative study of the toxicity of Fusarium verticillioides (=F.moniliforme) to horses. primates, pigs, sheep, and rats. Onderstepoort. J.Vet. Res. 48:129-131

; Marasas, W.F.O. \& Thiel, P.G. (1981). Hepato-and cardiotoxicity of Fusarium verticillioides (= F.moniliforme) isolates from southern African Maize. Food Cosmet. Toxicol. 19: 447-456

Kuthbuthee, A.J. \& Webster, J. (1986). Water availability and the coprophilous fungus succession. Trans. Br. mycol. Soc. 86:63-76

Lundqvist, N. (1969) Tripterospora (Sordariaceae s.lat.. Pyrenomycetes) Notaniska Notiser 122:589-603

(1972). Nordic Sodariaceae s.lat. Symbolae Botanicae Upsalienses 20:1-374

Miller, S.T. (1995) Functional diversity in fungi. Can, J. Bot.73(Suppl. 1) S50-S57.

Parker, A.D. (1979). Associations between coprophilous Ascomycetes and fecal sustrates in Illinois. Mrcologia 71:1206-1214

Piontelli, E.; Toro, S.M. M.A. \& Caretta,C. (1981). Coprophilous fungi of the horse. Mycopathologia 74:89-105

Richardson, M.J. (1972). Coprophilous Ascomycetes on different dung types. Trans. Br. mycol. Soc. 58:37-48

Safar, H.M. \& Cooke, R.C. (1988 a). Explotation of fecal resource units by coprophilous ascomycotina. Trans. Br. mycol. Soc. 90: 593-599

Safar, H.M. \& Cooke, R.C. (1988 b). Interactions between bacteria and coprophilous Ascomycotina and Coprinus species on agar and in copromes. Trans. Br. mycol. Soc. 91: 73-80

Seifert;K.A.; Kendrick, B. \& Murase, G. (1983). A key to Hyphomycetes on dung. University of Waterloo. Biology Series $n^{\circ} 27$. Waterloo, Ontario, Canada.

Shearer, C..A. (1995). Fungal competition. Can. J. Bot.73 (Suppl.1): S1259-S1264
Singh, N \& Webster,J. (1973). Antagonism by Stilbella erytrocephala and other coprophilous fungi. Trans. Br.myco. Soc. 60:487-495

Spegazzini, C. (1878). Fungi coprophili veneti - pugillus I. Michelia $1: 222-238$

Swart, H. J. (1967). Doratomyces columnaris sp.nov. Acta Bot. Neerlandica 15: 521-523

Udagawa,S. \& Takada, M. (1971). Soil and coprophilous microfungi. Bull. Nat. Sci. Mus. (Tokyo) 14:501-515

; Muroi, T.; Kurata,H.; Sexita, S.; Yashihira, K.; Natori, S. \& Umeda, M. (1979). The production of chaetoglobosins, sterigmatocystin, o-methylsterigmatocystin and chaetocin by Chatomium spp. and related fungi. Can J.Microbiol. 25:170-177

(1984). Taxonomy of mycotoxin producing Chaetomium. In: Kurata, H. \& Ueno, Y. (Eds.) Toxigenic fungi- their toxins and health hazard. Elsevier, Amsterdam. pp. 139-147

Vesco, G. dal. ;Peyronel, B.; Barge, M.T. \& Volpiano, N. (1967). Sulla micoflora dello sterco di coniglio (Oryctogalus cuniculus) Allionia $13: 107-127$

Wardle, D.A.; Parkinson, D \&. Waller, J.E. (1993). Interspecific competitive interactions between pairs of fungal species in natural substrates. Oecologia 94:165-172

Wicklow, D.T. \& Moore,V. (1974). Effect of incubation temperature on coprophilous fungal succession. Trans. Br. mycol. Soc. 62:411-414

Wicklow, D.T. (1979). Hair ornamentation and predator defense in Chaetomium. Trans. Brit. Mycol. Soc. 72: 107-110 \& Yocom.D.H. (1982). The effeet of larval grazing by Lycoriella mali (Diptera:Sciaridae) on species abundance of coprophilous fungi. Tran Br. mycol. Soc. 78:29-32

(1988). Metabolites in the coevolution of fungal chemical defense systems. In : Pirozynski, K.A.\& Hawksworth, D.L.(Eds.) Coevolution of fungi with plants and animals. Academic Press, London pp. 173-201 